\title{
Essential amino-acids of some tropical cereal millets
}

\author{
By N. G. BAPTIST And B. P. M. PERERA \\ Biochemical Laboratory, Department of Physiology, \\ University of Ceylon, Colombo \\ (Received ro May I956)
}

The millets are among the important minor cereals of tropical and subtropical regions, especially of India, Ceylon, Malaysia and Africa; a knowledge of their composition and nutritive value is therefore desirable. The determination of the essential amino-acids of sorghum (Andropogon sorghum) and finger millet (ragi, Eleusine coracana) has been described in a previous paper (Baptist, 1954). We report here the values obtained for the eight amino-acids indispensable for man (Rose, 1949) in the foxtail (Italian) millet or tanahal (Setaria italica Beauv.), the Indian (common) millet or maha meneri (Panicum miliaceum Linn.), the little millet or heen meneri (Panicum miliare Lamk.) and an indigenous millet, not previously described as growing in Ceylon, which has been identified as Brachiaria ramosa L. Stapf.

\section{EXPERIMENTAL}

Identification of the indigenous millet. This grain was originally sent to us as little millet (Panicum miliare Lamk.); however, we found it to have an unusually high nitrogen content which led us to suspect that we were dealing with a different species. Examination under high magnification confirmed this. Whereas the grains of the panicum species were brown in colour and showed a characteristic ovoid shape with alternating light and dark longitudinal bands, this grain had a distinctly different appearance (see Pl. I, I); the glumes were very characteristic being firmly adherent, unlike in the panicum species, in which they could be easily removed by lightly rubbing between the fingers. 'The husk was of a light straw shade and the cleaned grain, which had a prominent pigmented embryo, showed marked transverse rugosity and was intermediate in size between Panicum miliaceum and P. miliare (see Pl. I, 2). The grain was therefore referred to the Systematic Botanist of the Department of Agriculture who identified it as Brachiaria ramosa, formerly known as Panicum ramosum Koenig (Ferguson, 1879 ). In view of its characteristic glumes and the fact that it is regarded as a meneri (panicum) species by the rural population, the name 'pothu meneri' is suggested for this millet.

Preparation of material for analysis. Representative samples of each of the millets were lightly pounded in a mortar and winnowed. The process was repeated several times, the cleaned grain being removed from time to time till no unhusked grain remained. The cleaned samples were then ground to a fine powder and sifted through a $90-$ mesh Monel sieve. Fat extraction of the powders was omitted, as previous 
experience had shown no appreciable errors to be introduced by carrying out the analysis on the wholemeal from cereals.

Non-protein nitrogen. A weighed portion $(3-4 \mathrm{~g})$ of the powdered grain was shaken with $25 \mathrm{ml}$. of $5 \%$ trichloroacetic acid in a stoppered flask. Samples of the clear filtrate were taken for nitrogen determination.

Determination of nitrogen, preparation of the hydrolysates and methods of microbiological assay were carried out as described earlier (Baptist, 1954).

\section{RESULTS}

Table I shows the nitrogen and protein contents of the anhydrous materials. The corresponding figures for other representative cereals are given for comparison. The nitrogen values for wheat, rice and maize are calculated from the protein contents given by Chatfield (1949) by the use of the factors 5.83 for wheat, 5.95 for rice and $6 \cdot 25$ for maize. The nitrogen values for sorghum and finger millet are taken from Baptist (1954) and the factor 6.25 has been used for calculating the protein content.

\section{Table I. Nitrogen and protein contents of cereals (wholemeal)}

\begin{tabular}{|c|c|c|}
\hline Cereal & $\begin{array}{l}\text { Nitrogen in } \\
\text { anhydrous } \\
\text { wholemeal } \\
(\%)\end{array}$ & $\begin{array}{c}\text { Protein* in } \\
\text { anhydrous } \\
\text { wholemeal } \\
(\%)\end{array}$ \\
\hline Little millet (Panicum miliare Lamk.) & $1 \cdot 60$ & 10.0 \\
\hline Foxtail millet (Setaria italica Beauv.) & $2 \cdot 02$ & $12 \cdot 7$ \\
\hline Indian millet (Panicum miliaceum Linn.) & $2 \cdot 19$ & $13 \cdot 7$ \\
\hline Brachiaria millet (Brachiaria ramosa L. Stapf.) & $3 \cdot 18$ & $19^{\circ} 9$ \\
\hline Finger millet (Eleusine coracana) $\dagger$ & $1 \cdot 26$ & $7 \cdot 9$ \\
\hline Sorghum (Andropogon sorghum) $\dagger$ & $I \cdot 93$ & $12 \cdot 1$ \\
\hline Wheat $:$ hard & $2 \cdot 69$ & $15 \% 7$ \\
\hline soft & $2 \cdot 04$ & II 9 \\
\hline Maize $\ddagger$ & $x \cdot 73$ & $10 \cdot 8$ \\
\hline Ricet & $\mathrm{I} \cdot 45$ & $8 \cdot 6$ \\
\hline
\end{tabular}

Table 2 gives the values obtained for the eight essential amino-acids in each cereal. The amino-acid contents are shown along with figures for finger millet, sorghum and rice (Baptist, 1954), wheat and maize (Jones, Caldwell \& Widness, 1948) and ovalbumin (Block \& Bolling, I95 I) for comparison.

The non-protein nitrogen content of Brachiaria ramosa was found in duplicate determinations to be $\mathrm{x} \cdot 53$ and $\mathrm{I} \cdot 55 \%$ of the total nitrogen.

\section{DISCUSSION}

Protein content. The figures in Table I show that the protein contents of these millets are fairly high, Indian and foxtail millets being on par with wheat, and little millet inferior to wheat though superior to rice. The millet Brachiaria ramosa is exceptionally rich in nitrogen, and the protein content calculated on the usual basis yields a figure higher than any we can find in the literature on cereals. This high value 
$\frac{2}{2}$

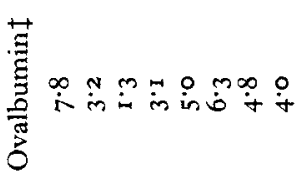

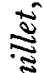

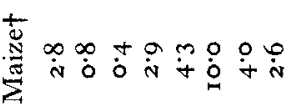

ป

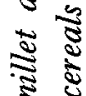

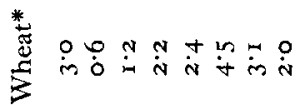

章

著

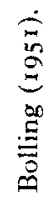

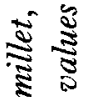

* क

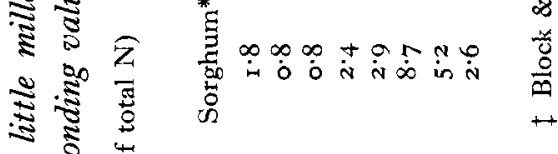

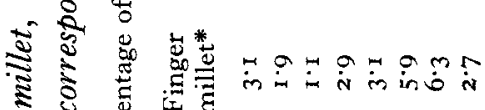

范茫

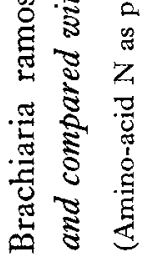

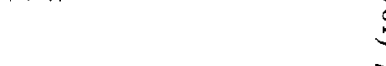

$\stackrel{\infty}{+\infty}$

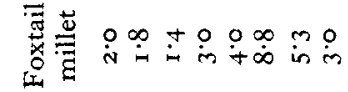

gृ

.

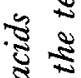

i.

竎

䒿苛

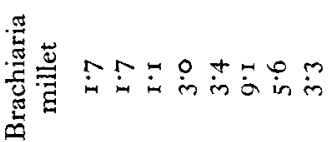

.

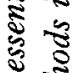

$+$

s)

胥

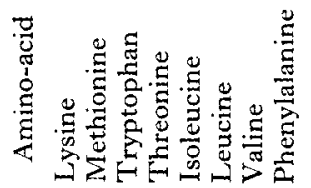

$\dot{\mathrm{i}}$

$\frac{0}{\frac{0}{0}}$ 

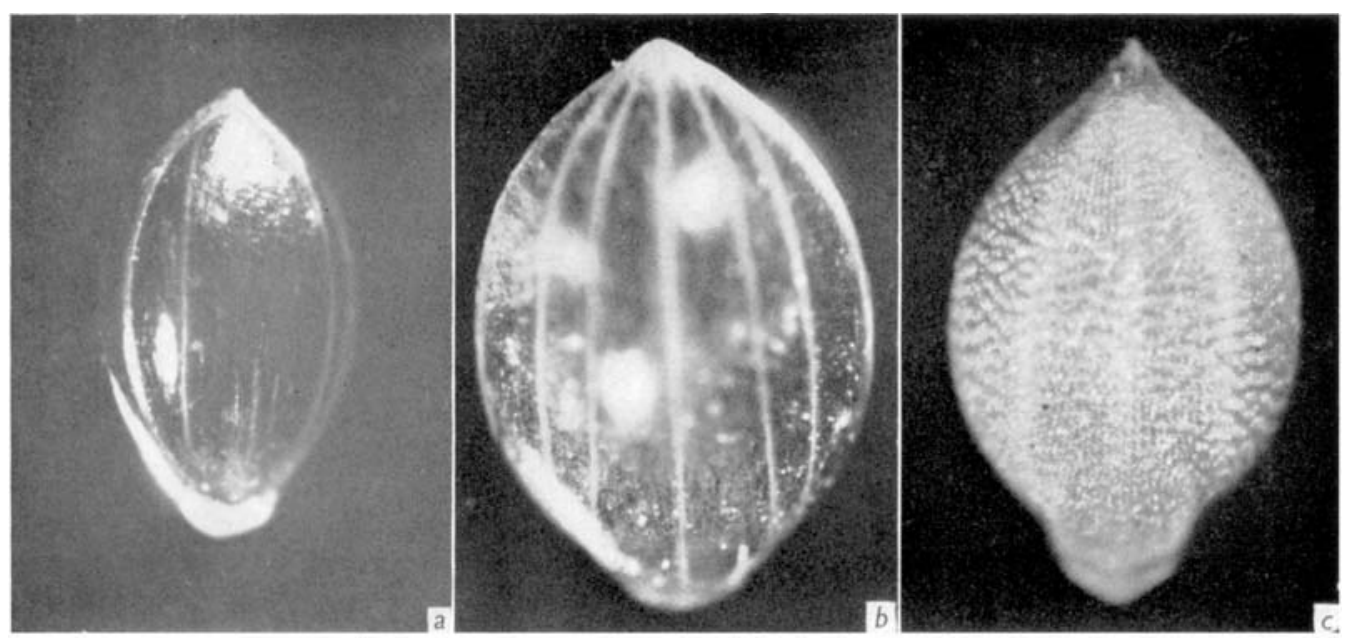

I
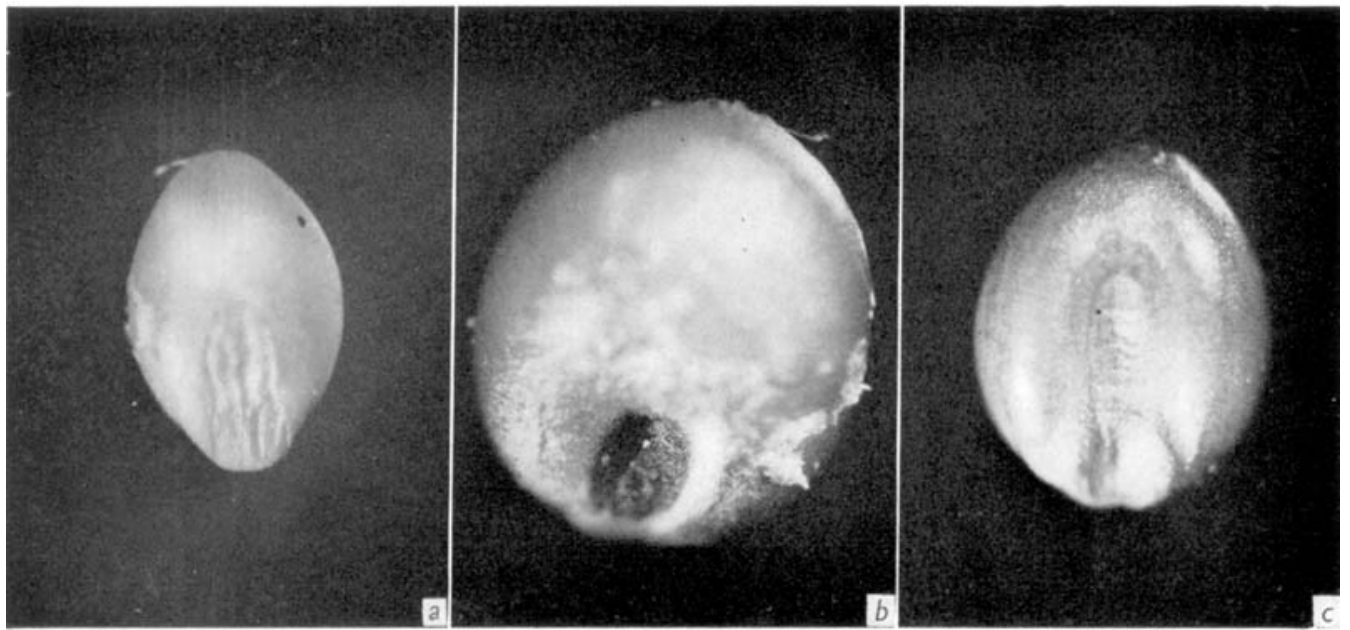

2

British Fournal of Nutrition, Vol. ıо, No. 4

(Fiacing p. 337) 
is of interest in view of the current emphasis on the need for a high protein content in the diets of peoples in underdeveloped areas of the world. That the high nitrogen content of $B$. ramosa is not due to a high non-protein nitrogen content seems likely, since the distribution of its amino-acid nitrogen is similar to that in the other millets (Table 2). In view also of the low non-protein nitrogen content, it is reasonable to conclude that the bulk of the nitrogen in this millet is protein nitrogen.

Essential amino-acid distribution. The figures in Table 2 reveal a very similar pattern of amino-acid distribution in the millets. The lysine content is low and the methionine content is high, as found previously for finger millet (Baptist, 1954). Of these grains, foxtail millet (tanahal) has a decidedly higher tryptophan content than the others. It is interesting to recall here the high lysine content and low methionine content of the pulses, because the combination of these two groups of foodstuffs, the millets and the pulses, which form the basic diet of many primitive tribes, gives a well-balanced mixture of the essential amino-acids, though each group by itself is seriously lacking in at least one of the essential amino-acids.

\section{SUMMARY}

r. Eight essential amino-acids have been determined in four millets commonly consumed in Ceylon and other tropical countries.

2. The results show a similar essential amino-acid pattern. All the millet proteins are characterized by a high methionine and low lysine content.

3. One of the millets, considered by the indigenous population to be little millet or heen meneri (Panicum miliare Lamk.), has been now identified as Brachiaria ramosa L. Stapf. and shown to be exceptionally rich in protein.

4. The amino-acid content of these millets is compared with figures for other representative cereals and their nutritive value briefly discussed in relation to their contents of protein and essential amino-acids.

The authors wish to thank Mr R. D. Sothary for technical assistance; the Director of Agriculture, Peradeniya, Ceylon, for supplying the samples of millets; Mr J. E. Senaratna, Systematic Botanist, Department of Agriculture, Ceylon, for his identification of the millet Brachiaria ramosa L. Stapf., and Mr G. Webster for the photographs.

\section{REFERENCES}

Baptist, N. G. (1954). Brit. F. Nutr. 8, 218.

Block, R. J. \& Bolling, D. (I95I). The Amino Acid Composition of Proteins and Foods, and. ed. Springfield, Ill. : Charles C. Thomas.

Chatfield, C. (1949). F.A.O. nutr. Stud. no. 3.

Ferguson, W. (1879). I. Ceylon Br. Asiat. Soc. p. 6r.

Jones, D. B., Caldwell, A. \& Widness, K. D. (1948). F. Nutr. 35, 639.

Rose, W. C. (1949). Fed. Proc. 8, 546.

\section{EXPLANATION OF PLATE}

1. Grain in husk. (a) Panicum miliare Lamk.; (b) P. miliaceum Linn.; (c) Brachiaria ramosa L. Stapf. $\times 19.5$.

2. Cleaned grain. (a) Panicum miliare Lamk.; (b) P. miliaceum Linn.; (c) Brachiaria ramosa L. Stapf. $\times 19.5$. 